\title{
Analysis of Tax Management Through Corporate Loss Compensation Scheme
}

\author{
*Desiana, **Arinal Nurrisyad Hanum \\ DOI: 10.29322/IJSRP.11.12.2021.p12060 \\ http://dx.doi.org/10.29322/IJSRP.11.12.2021.p12060
}

\begin{abstract}
This study aims to analyze the role of compensation for losses in corporate tax management in Indonesia. The approach used in this research is a literature approach or literature study. Secondary research data were collected from books, journals, laws and regulations. This study found that compensation for losses is one of the efforts in tax management to streamline income tax costs for corporate taxpayers in the present and in the future.
\end{abstract}

Index Terms- tax planning, corporate income tax, loss compensation

\section{A. INTRODUCTION}

The Covid-19 virus pandemic in Indonesia has occurred since March 2020 until now. This causes various major impacts on various sectors of life, especially in the field of the global economy and finance. For Indonesia itself, the Minister of Finance, Sri Mulyani Indrawati, predicts economic growth in the worst case scenario could reach minus $0.4 \%$. Weak economic growth has a significant impact on state revenues. The Directorate General of Taxes (DGT) as the government authority responsible for state revenues makes various efforts in order to boost tax revenues from taxpayers. Meanwhile, entrepreneurs as taxpayers try to keep their tax payments to a minimum, legally or illegally. The legal method is commonly known as tax planning, while the illegal method is commonly known as tax evasion.

In Law Number 17 of 2003 concerning State Finances it is stated that state revenues are all revenues originating from tax revenues, non-tax state revenues and grant receipts from within and outside the country. Taxation is the largest source of state revenue, as evidenced by data from the 2017-2020 State Revenue and Expenditure Budget (APBN) that around 88.95\% of state revenue comes from tax revenues (LKPP, 2021). During this Covid-19 Pandemic, DGT will try to optimize tax revenue by prioritizing three spearheads, namely:

1. Account Representative (AR) through supervision and consultation,

2. Examiner/investigator through examination, examination of preliminary evidence, and investigation, as well as

3. Bailiff through tax collection

The economic conditions affected by the Covid-19 pandemic are undeniably causing many companies to suffer losses. In the event of a loss, the company does not need to pay taxes for the year or even claim back the taxes that have been paid previously. Losses can also help companies to save on taxes that must be paid for the following year through a compensation scheme. The loss referred to in the compensation scheme is a fiscal loss. Meanwhile, in accounting, the loss suffered by the company is a commercial loss. Differences in viewpoints and applicable regulations lead to different compensation schemes for fiscal and commercial losses. In this case, the tax audit process is the first door in determining the final figure that can be used by corporate taxpayers to save on tax payments. How companies can account for reported losses is an important part of tax management.

For companies, taxes are a burden that will reduce net income, so the company seeks to keep tax payments to a minimum. This creates a difference of interest between the tax authorities (tax collectors) who want maximum tax revenue and companies as taxpayers who want minimal tax payments. On the other hand, when the company suffers a loss, it can be said that the company's performance in that year is not good. The consideration of utilizing the loss compensation facility is an issue that is considered because the company must prepare time and money to face tax audits in accounting for the loss in a fiscal manner to the tax authorities. When the company's performance is not good, the company is not only preoccupied with efforts to recover the company's profits so that it can continue to operate but also has to face tax audits. Therefore, good tax management is needed to minimize the time and costs.

\section{B. CONCEPTUAL FRAMEWORK}

According to Permatasari (2004), tax management is the management of the obligation to fulfill the company's tax obligations correctly and properly so that the amount of tax can be reduced as low as possible to get the expected profit without 
elements of violations that can lead to sanctions or fines. Tax planning through tax avoidance is the only legal way to streamline tax payments.

According to Pohan (2013), the company's efforts to minimize its tax burden are called tax planning. Tax planning that is carried out legally and does not conflict with tax regulations is called tax avoidance, while tax planning that is carried out illegally and contrary to tax regulations is called tax evasion.

Pohan (2013) explains tax avoidance as one of the active tax resistance efforts, namely all efforts and actions that are directly addressed to the tax authorities and aim to avoid taxes. The methods and techniques used are by exploiting the weaknesses (grey areas) contained in the tax law and regulations themselves, to reduce the amount of tax payable. The amount of tax avoidance can be seen from the comparison between cash spent on tax costs and profit before tax (Cash Effective Rate / CETR) (Dryeng, Hanlon \& Maydew, 2010).

In carrying out tax management, it is necessary to carry out proper tax planning so that the purpose of tax management can be achieved. According to Suandy (2008), there are several aspects in tax planning including:

1. Formal and administrative aspects

The formal aspect that must be considered by every taxpayer is that the taxpayer must comply with the applicable tax laws so as not to be subject to sanctions, both administrative sanctions and criminal sanctions. The imposition of sanctions is a waste of resources that needs to be avoided, and this can be achieved through a good tax planning. Of course, to be able to compile a good tax plan, it is necessary to understand the tax regulations and follow developments so that if there are changes in regulations, they can be immediately applied to the tax planning that has been prepared. While the administrative aspects include the obligation to register to obtain a NPWP and the Inauguration of a Taxable Entrepreneur (PKP), maintain books or records, pay taxes and report taxes before maturity.

2. Material aspect

Taxes are imposed on tax objects which can be in the form of circumstances, actions or events. The basis for calculating taxes is the tax object, so in order to optimize the allocation of sources of funds, management will plan tax payments that are no more (because it can reduce the optimization of resource allocation) and no less (so as not to pay administrative sanctions which are a waste of funds). Thus, the reported tax object must be materially correct and complete and there is no negative engineering.

A company has a large room to make income tax efficiency efforts (Cao \& $\mathrm{Xu}, 2009)$. There are many tax planning approaches that companies can take. One of them is choosing the form of organization of a company. Companies that experience profits can do business mergers or acquisitions to companies that lose to compensate for the profits that have been owned by a company.

Tax management should be applied to enrich the company's strategy and not distance it from the company's intended strategy. A company may have zero operating profit and pay no taxes, but this is inconsistent with the strategic objectives of a company. Therefore, managers must know about taxation because the key to success in minimizing the tax burden is decided by managers in an organization (Karayan, Swenson \& Neff, 2002).

According to the OECD (2011), aggressive tax planning is increasingly being found. There are several important areas that need to be considered related to reporting losses experienced by a company. The use of financial instruments, corporate reorganization, and unreasonable transfer prices are key concerns that must be investigated by the tax authorities in reporting losses of a company in that country.

According to Ginting (2016), fiscal loss or gain is the difference between income and costs that take into account income tax provisions. Fiscal loss compensation can be defined as the process of transferring losses from one period to the next. According to research conducted by Ginting (2016), fiscal loss compensation has a significant effect on tax avoidance in manufacturing companies listed on the Indonesia Stock Exchange. This research is in line with the research of Fauziah, Iskandar, and Kusumawardani (2020); Reinaldo, Zirman, and Rusli (2017). Meanwhile, according to research by Andriyani and Mahpudin (2021), Fiscal loss compensation has no significant effect on tax avoidance in mining companies listed on the Indonesia Stock Exchange.

\section{RESEARCH METHOD}

The research methodology used is qualitative. Raco (2013) states that qualitative research is a theoretical idea with techniques and procedures to reveal facts to obtain information. The source of the data taken is secondary data, which is not obtained directly from the data source (Sugiyono, 2018). Secondary data in the form of other people's research, reviews, and summaries. In this study, the data taken is literature data that explains tax management, tax planning, tax avoidance, tax accounting, compensation for losses. Data and information supporting this writing were collected by conducting library searches, searching relevant sources, and browsing data through the internet. The data and information used are electronic media data, tax regulations, and previous research. The data collection techniques are:

1. Track tax rules;

This publication is licensed under Creative Commons Attribution CC BY.

http://dx.doi.org/10.29322/IJSRP.11.12.2021.p12060

wWw.ijsrp.org 
2. Conduct reference searches in the form of articles in electronic media to support discussion and analysis

\section{E. RESULT AND DISCUSSION}

The company in running a business certainly aims to maximize profits or profits. But on the other hand, it is undeniable that there are businesses that under certain conditions experience losses. When the business experience losses, the company can consider the tax benefits that can be used in the future time from the losses. Companies can determine sustainable strategies in tax managements. When the company has been able to operate well (started to perform positively or generate profits) in tax treatment in Indonesia, previous losses can reduce corporate taxes in the current year and even in the next few years. It should be considered in tax management not only to save on tax payments which is the only goal in a company's tax planning. When companies do tax planning, of course there are also costs that must be incurred. In this case there must be a balance point where the planning is correct to produce cost efficiency. If it only saves taxes but incurs other costs that are greater than the saved taxes, the tax planning becomes useless.

Tax management can be carried out in many ways. One of them is through a loss compensation scheme. Fiscal loss compensation is a compensation scheme carried out by corporate taxpayers and individual taxpayers who, based on their books, suffer losses. When the company suffers a loss and reports a fiscal loss, an inspection or tax audit will be carried out to test the compliance with the report. The aim is to verify whether the fiscal loss is true or not. If the results of the examination state that they approve of the reported fiscal loss, apart from the amount of tax that will be returned to the taxpayer, the loss can also be used by the company to reduce tax payments in the next period. In Indonesia, compensation for losses can be made for 5 consecutive years starting from the next tax year.

Fiscal losses are losses based on tax assessments that have been issued by the DGT and losses based on the Taxpayer's Annual Income Tax Return (self-assessment) in the event that there is no or no tax assessment has been issued by the DGT. Fiscal loss compensation arises if in the previous tax year there was a fiscal loss (Annual SPT is reported as Nil or Overpaid but there is a fiscal loss). Fiscal losses occur because when gross income is reduced, the result is a loss. The loss can be compensated with net taxable profit starting in the next tax year in a row up to five years.

Provisions regarding the period of recognition of fiscal loss compensation have been in effect since 2009. If at a later date based on the tax assessment results, the results of the audit show that the amount of fiscal loss is different from the loss according to the Annual Income Tax Return or the results of the audit become no loss, the tax loss compensation must immediately be revised in accordance with with the provisions and procedures for the correction of the Annual Income Tax Return as regulated in the Law on General Provisions of Taxation. The compensation for losses does not apply to Taxpayers whose total income is Final and or is not a tax object. In addition, losses suffered from abroad cannot be included in the calculation of compensation for fiscal losses.

With the development of technology, commercial or fiscal loss schemes have become interesting issues to pay attention to. Whether the loss is planned in order to save some corporate tax without disrupting the company's overall operations. Multinational companies generally cannot avoid the so-called transfer pricing policy. The transfer pricing policy is one of the methods commonly applied by companies commercially with a specific purpose. Through the transfer pricing that is determined between companies between groups within one group, it can cause losses in one of the companies giving or receiving. The COVID-19 pandemic is also one of the common reasons and it is natural for companies to experience losses during a weakening economy like today. The tax system in Indonesia adheres to self-assessment so that tax management is carried out in determining transfer prices to create losses in a company. In accordance with the laws in force in Indonesia, losses abroad cannot be calculated domestically. Through the transfer pricing method, these losses can indirectly be transferred into Indonesia. It is undeniable that a similar method can be applied by local companies between groups in managing corporate taxes.

Taxpayers can also create artificial loss schemes by creating artificial deductions through a series of transactions, such as by performing intra-group asset transfers that result in capital gains at the level of one group member and an associated increased tax base for depreciation purposes at the level of another group member, furthermore, unrelated banks create artificial interest deductions for taxpayers through the loan chain. The tax liability on capital gains is thus offset through interest payments on loans purportedly made to acquire participation which results in the exempted dividend income. These schemes can involve a number of companies and there appears to be no underlying cash flow movement for tax purposes with no economic loss to anyone.

Therefore, companies in preparing tax planning need to pay attention to whether the steps taken pass the existing rules or not. According to the author, several things that need to be considered in tax planning include considering the tax impact of each transaction that will be carried out. In addition, there is a need for an understanding of taxation issues including the tax law, government regulation (PP), the Minister of Finance, Perdirjen, or Circular (SE). Companies need to ensure that in carrying out corporate tax planning they do not violate tax provisions, make business sense logically and are supported by adequate evidence. 


\section{F. CONCLUSION}

Loss compensation is one of the tax management methods that can be categorized as tax avoidance because it does not violate the applicable rules. In the event that the company will carry out tax management through a loss compensation scheme, taxpayers need to have good bookkeeping and carry out tax obligations in accordance with applicable tax regulations. If this can be implemented properly, then when the taxpayer is subjected to a compliance test, which is the function of the government as a supervisor in the self-assessment system, the loss can be properly accounted for. In the event that the results of the examination state that they approve the reported fiscal loss, apart from the amount of tax that will be returned to the taxpayer, the loss can also be used by the company to reduce tax payments in the next period. In Indonesia, compensation for losses can be carried out for 5 years, so here the role of tax planning, tax organizing, tax leading, and controlling tax is very important. With good tax management, efficiency and effectiveness which is the goal of tax management can be achieved.

\section{REFERENCES}

[1]Andriyani, M. \& Mahpudin, E. 2021. Pengaruh Corporate Governance Dan Kompensasi Rugi Fiskal Terhadap Tax Avoidance: Studi Empiris Pada Perusahaan Pertambangan Yang Terdaftar Di Bei Tahun 2017-2019. http://dx.doi.org/10.29040/jap.v21i02.1431.

[2] Cao, H. \& Xu, X. 2009. Study on The Tax Planning Enterprise Income Tax. International Journal of Business and Management. Vol.4(5), 36-40.

[3] Dyreng, S. D. Hanlon, M. \& Maydew, E. L. 2010. The Effect of Executives on Corporate Tax Avoidance. The Accounting Review Vol.85 No.4 pp. 1163 1189.

[4] Fauziah, D.P., Iskandar, I, \& Kusumawardani, A. 2020. Pengaruh kompensasi rugi fiskal, kepemilikan institusi, return on asset, dan leverage terhadap penghindaran pajak pada perusahaan otomotif yang terdaftar di bursa efek Indonesia. http://dx.doi.org/10.29264/jiam.v5i3.6672

[5] Ginting, S. 2016. Pengaruh Corporate Governance dan Kompensasi Rugi Fiskal Terhadap Penghindaran Pajak dengan Ukuran Perusahaan Sebagai Variabel Moderating. Jurnal Wira Ekonomi Mikroskil. Vol.6(2), 165-175.

Karayan, J. E., Swenson, C.W., Neff, J.W. 2002. Strategic Corporate Tax Planning. Canada: John Wiley \& Sons, Inc., Hoboken, New Jersey.

[6] Kementerian Keuangan Republik Indonesia. 2021. Laporan Keuangan Pemerintah Pusat (LKPP). https://www.kemenkeu.go.id/publikasi/laporan/laporankeuangan-pemerintah-pusat/

[7] Organisation for Economic Cooperation and Development. 2011. Corporate Loss Utilisation through Aggressive Tax Palnning. Paris: OECD Publishing.

[8] Pohan, C. A. 2013. Manajemen Perpajakan: Strategi Perencanaan Pajak dan Bisnis. Jakarta.

[9] Permatasari, P. 2004. Transfer Pricing sebagai Salah Satu Strategi Perencanaan Pajak Bagi Perusahaan Multinasioal. Jurnal Bina Ekonomi, Vol.8(1),1-109.

[10] Raco, J.R. 2013. Metode Penelitian Kualitatif Jenis Karakteristik dan Keunggulannya. Jakarta: Grasindo.

[11] Reinaldo, R., Zirman, \& Rusli. 2017. Pengaruh Leverage, Ukuran Perusahaan, ROA, Kepemilikan Institusional, Kompensasi Kerugian Fiskal, dan CSR terhadap Tax Avoidance Pada Perusahaan Manufaktur Subsektor Makanan dan Minuman Terdaftar Di BEI 2013-2015. Vol.4(1).

[12] Republik Indonesia. Undang-Undang No. 36 Tahun 2008 tentang Perubahan keempat Undang-Undang No. 7 tahun 1983 tentang Pajak atas Penghasilan.

[13] Republik Indonesia. Undang-Undang Nomor 17 Tahun 2003 tentang Keuangan Negara.

[14] Suandy, Erly. 2008. Perencanaan Pajak. Jakarta: Salemba Empat.

[15] Sugiyono. 2016. Metode Penelitian Kuantitatif Kualitatif dan R\&D. Edisi Kedua. Bandung: Alfabeta

\section{AUTHORS}

First Author - Desiana, desianazhang@yahoo.com

Second Author - Arinal Nurrisyad Hanum, wardiyana30@gmail.com

Correspondence Author - Desiana, desianazhang@yahoo.com 